\title{
Potent glycogenic effect of GLP-1(7-36)amide in rat skeletal muscle
}

\author{
M. L. Villanueva-Peñacarrillo, A. I. Alcántara, F. Clemente, E. Delgado, I. Valverde \\ Department of Metabolism, Nutrition and Hormones, Fundacióní Jiménez Díaz, Madrid, Spain
}

Summary GLP-1(7-36)amide is an intestinal posttranslational proglucagon product released mainly after carbohydrate ingestion, the glucose dependent insulinotropic and antidiabetogenic actions of which have been documented. In this work, by exploring whether GLP-1(7-36)amide has any effect on the glucose metabolism of the muscle, we have observed that this peptide, at physiological concentrations, exerts in this tissue an increment of the D-[U${ }^{14} \mathrm{C}$ glucose incorporated into glycogen, which is accompanied by an increase in the glycogen synthase $a$ activity; also, it stimulates both glucose oxidation and lactate formation. These data indicate that the skeletal muscle is one of the target tissues for GLP1(7-36)amide, where its insulin-like effect explains, at least in part, its plasma glucose lowering action; thus, GLP-1(7-36)amide may well be implicated in the physiological control of glucose homeostasis after meals, not only by acting as an incretin, but also by directly promoting glucose disposal. [Diabetologia (1994) 37: 1163-1166]

Key words GLP-1(7-36)amide, glycogenesis, skeletal muscle.
The glucose-dependent insulinotropic proglucagonderived peptide GLP-1(7-36)amide, which is released mainly after glucose [see Ref.1, for review] has an antidiabetogenic action in normal and diabetic states [2]. In this work we have explored whether GLP-1(7-36)amicle could have insulin-like effects on glucose metabolism in the muscle.

\section{Materials and methods}

Wistar rats, weighing 200-250 g and kept on a standard pellet diet (UAR, Panlab, Barcelona, Spain) with tap water ad libitum, were used. For glycogen synthesis studies, the rat was kil-

Received: 17 June 1994

and in revised form: 12 August 1994

Corresponding author: Dr. M.L. Villanueva-Peñacarrillo, Departamento de Metabolismo, Nutrición y Hormonas, Fundación Jiménez Díaz, Avenida Reyes Católicos, 2, E-28040 Madrid, Spain

Abbreviations: KRB, Krebs-Ringer bicarbonate buffer, $\mathrm{pH}$ 7.4; EDTA, ethylenedinitrilo tetraacetic acid, disodium salt dihydrate; BSA, bovine serum albumin. led by a blow to the head, and the two intact soleus muscles were removed, then individually attached by the tendon to a steel clip [3]. After rinsing in saline solution, they were immediately preincubated at $37^{\circ} \mathrm{C}$ in $1.5 \mathrm{ml}$ Krebs Ringer buffer (KRB) containing $1 \%$ bovine serum albumin (BSA) and $5 \mathrm{mmol} / 1 \mathrm{D}$-glucose for $30 \mathrm{~min}$, while undergoing continuous gentle shaking. Preincubation was followed by incubation for $60 \mathrm{~min}$, for which the muscles were transferred to another vial containing the same medium except for the presence of $0.35 \mu \mathrm{Ci} D-\left[\mathrm{U}-{ }^{14} \mathrm{C}\right]$ glucose and $0.3 \mu \mathrm{Ci}$ D- $\left[5-{ }^{3} \mathrm{H}\right]$ glucose (both from Amersham, Little Chalfont, Bucks., UK), and either without (control) or with different concentrations of GLP1(7-36)amide (Peninsula Lab. Inc., Belmont, Calif., USA) or rat insulin (Novo-Nordisk, Bagsvaerd, Denmark). During the preincubation and incubation, an atmosphere of $\mathrm{O}_{2} / \mathrm{CO}_{2}$ $(95: 5)$ was maintained in the vials sealed with a rubber stopper. Paired soleus muscles from one animal were used in each experiment, using one of the pair as control (absence of peptide or otherwise stated). At the end of the incubation period, each muscle was quickly washed in the same ice-cold media except for the absence of radioactivity and BSA. To further control the effect of GLP-1(7-36)amide on glycogen synthesis, an equimolar amount $\left(10^{-10} \mathrm{mmol} / \mathrm{l}\right)$ of the peptide was pre-treated with an excess of a C-terminal glucagon-like peptide 1 (GLP-1) antiserum (no.2135, a gift from Dr. J. J. Holst, Copenhagen, Denmark), for 4 days at $4{ }^{\circ} \mathrm{C}$; the degree of GLP-1(736) amide bound (mean $\pm \mathrm{SEM} ; 100 \pm 1, n=7$ ) was measured 


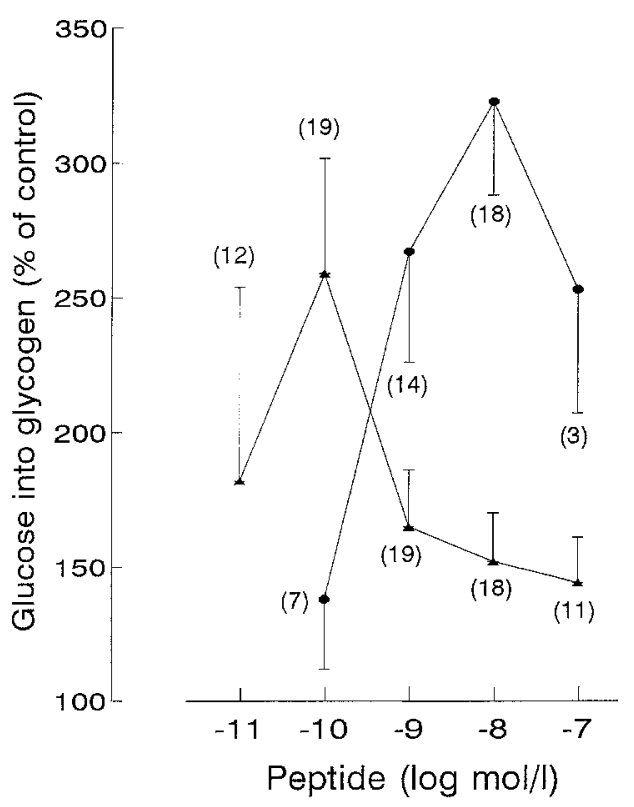

Fig. 1. Incorporation of $\mathrm{D}-\left[\mathrm{U}_{-}{ }^{14}\right.$-C]glucose into cellular glycogen. Mean values ( \pm SEM) correspond to the number of experiments, given in parentheses, for each peptide concentration. Values are expressed as percent of the control value, $2.3 \pm 0.2 \mathrm{nmol}$ glucosyl units $/ \mathrm{mg}$ protein, $n=121$, in $60 \mathrm{~min}$. One glucosyl unit indicates one glucose moiety incorporated into glycogen

in parallel samples containing, in addition, tracer amounts of [ $\left.{ }^{125} \mathrm{I}\right]$-GLP-1(7-36)amide.

Radioactive glycogen content. To determine the D-[U${ }^{14} \mathrm{Clglucose}$ incorporated into glycogen, the procedure described by Cuendet et al. [4] was basically followed; each muscle was extracted in $1 \mathrm{ml} 1 \mathrm{~N} \mathrm{NaOH}$ for $10 \mathrm{~min}$ at $70^{\circ} \mathrm{C}$; after an aliquot sample $(10 \mu \mathrm{l})$ had been taken for determination of total protein content by the Bradford method using BSA as standard (Bio-Rad protein assay, Bio-Rad, Munich, Germany), glycogen was precipitated with $85 \%$ (v/v final) ethanol at $4{ }^{\circ} \mathrm{C}$, in the presence of previously added carrier unlabelled glycogen $(100 \mu \mathrm{g} / \mathrm{ml}$, final). The precipitate was then sedimented by centrifugation, redissolved in $0.5 \mathrm{ml}$ water, and the ${ }^{14} \mathrm{C}$ content measured in $5 \mathrm{ml}$ scintillation liquid (Ultima Gold, Packard, Groningen, The Netherlands).

${ }^{14} \mathrm{CO}_{2},{ }^{3} \mathrm{HOH}$ and lactate production. ${ }^{14} \mathrm{CO}_{2},{ }^{3} \mathrm{HOH}$ and lactate were measured simultaneously in most of the experimental samples used to study glycogen synthesis. The basic procedure described elsewhere [5] was followed; in brief, two cups with cellulose Whatman paper, one of which contained $0.5 \mathrm{ml}$ $0.1 \mathrm{~mol} / 1 \mathrm{HCl}$ for ${ }^{3} \mathrm{HOH}$ uptake, were hung from the rubber stopper during the muscle's 60-min incubation period. Then, $250 \mu \mathrm{l}$ hyamine hydroxide (Hopkins \& Williams, Chendwell Heath, UK) was injected into the second cup, for ${ }^{14} \mathrm{CO}_{2}$ uptake, and after $3 \mathrm{~min}$ at $4^{\circ} \mathrm{C}$, the muscle was removed and the cups subjected to a $30-\mathrm{min}$ incubation at $37^{\circ} \mathrm{C}$ followed by $60 \mathrm{~min}$ at $25^{\circ} \mathrm{C}$; after which the cups were separately placed in $5 \mathrm{ml}$ of scintillation liquid for ${ }^{3} \mathrm{H}$ and ${ }^{14} \mathrm{C}$ content measurements. To control the ${ }^{3} \mathrm{HOH}$ recovery, a vial with $1.5 \mathrm{ml}$ of the same medium containing $4 \mathrm{nCi}{ }^{3} \mathrm{HOH}$ (NEN Dupont Co., Brussels, Belgium), but containing no muscle, followed the whole procedure in each experimental set. Double-channel counting indicated the absence of cross-contamination. The medium was saved for lactate content determination, which was enzymatically assayed.
Glycogen synthase a and -phosphorylase a activities. Paired soleus muscles from one animal were used in each experiment, with one of the pair as control (absence of peptide). Muscles were preincubated for $30 \mathrm{~min}$ at $37^{\circ} \mathrm{C}$ in $1.5 \mathrm{ml} \mathrm{KRB}$ containing $1 \% \mathrm{BSA}$ and $5 \mathrm{mmol} / \mathrm{l} \mathrm{D}$-glucose; preincubation was followed by $10 \mathrm{~min}$ incubation in the same medium except for the presence of $16.7 \mathrm{mmol} / \mathrm{l} \mathrm{D}$-glucose, and in the absence (control) and presence of rat insulin $\left(10^{-8} \mathrm{~mol} / \mathrm{l}\right)$ or GLP-1(736)amide $\left(10^{-10}\right.$ and $\left.10^{-9} \mathrm{~mol} / \mathrm{l}\right)$. At the end of the incubation period, each muscle was placed in liquid nitrogen and, when frozen, broken into particles by a steel hammer blow; immediately the tissue was resuspended in $500 \mu \mathrm{l}$ ice-cold $50 \mathrm{mmol} / \mathrm{l}$ glycylglycine, $\mathrm{pH} 7.4$, containing $0.5 \%$ glycogen and $35 \mathrm{mmol} /$ 1 EDTA, and then subjected to further homogenization by Polytron (Ystral 1500, Göttingen, Germany). After debris was removed by sedimentation at $200 \mathrm{~g}$ for $2 \mathrm{~min}$, the supernatant was divided into two parts: one $(30 \mu \mathrm{l})$ was used for cyclic AMP determination and, to the other $(400 \mu \mathrm{l}), 100 \mathrm{mmol} / \mathrm{l} \mathrm{fi-}$ nal NaF was added for glycogen synthase $a$ and -phosphorylase $a$ activity determinations, which were assayed by the method of Hue et al. [6] except for the final glycogen extraction which was peformed as described by Fleig et al. [7].

Adenylate cyclase activity. The homogenized muscle aliquot samples taken during several of the experiments performed to study glycogen synthase $a$ and glycogen phosphorylase $a$, were treated with $65 \%$ (final) ethanol and, after centrifugation, the supernatants were evaporated and reconstituted for cyclic AMP assay (RIANEN cAMP [ ${ }^{125}$ I]RIA Kits, Dupont Co., Brussels, Belgium).

\section{Statistical analysis}

Results are expressed as mean \pm SEM. Statistical significance of the increments were assessed by the Student's $t$-test. Analysis of variance was also performed when appropriate.

\section{Results}

Figure 1 shows the dose-dependent effect of GLP1(7-36)amide and of insulin on glycogen formation in rat soleus muscle. GLP-1(7-36)amide significantly increased the incorporation $\mathrm{D}-\left[{ }^{14} \mathrm{C}\right]$ glucose into glycogen $(p<0.001, d f=157$, as determined by analysis of variance), as it did insulin $(p<0.001, d f=83)$. The maximal increment induced by GLP-1(7-36)amide was detected at $10^{-10} \mathrm{mmol} / \mathrm{l}$, and although significant increments over basal ( $p<0.05$ or less) were still observed at $10^{-9}-10^{-7} \mathrm{~mol} / \mathrm{l}$, those were lower than that attained at $10^{-10} \mathrm{~mol} / 1$ ( $p<0.05$ or less). As each value was obtained in individual experiments using paired muscle from the same rat as control without peptide, a further series of experiments was performed whereby one of the two muscles was incubated in the presence of GLP-1(7-36)amide at $10^{-10}$ $\mathrm{mol} / 1$, and the other at $10^{-9} \mathrm{~mol} / 1$. The $10^{-10} / 10^{-9}$ ratio value was $1.67 \pm 0.42(n=7)$, which is not different from that of the mean values of the two concentrations obtained in different experiments $(1.57 \pm 0.33$, $n=19)$. When the equimolar amount of GLP-1 
Table 1. Effect of GLP-1(7-36)amide and of insulin, on glucose oxidation $\left({ }^{14} \mathrm{CO}_{2}\right)$ and utilization $\left({ }^{3} \mathrm{HOH}\right.$ formation) and lactate release, during $60 \mathrm{~min}$ incubation. Data are expressed as percent of the control paired value. Control values: ${ }^{14} \mathrm{CO}_{2}$, $153 \pm 14, n=106, \mathrm{pmol}$ glucose/mg protein; ${ }^{3} \mathrm{HOH}, 43 \pm 5$, $n=106$, nmol glucose $/ \mathrm{mg}$ protein; lactate, $89 \pm 4, n=106$, $\mathrm{nmol} / \mathrm{g}$ protein

\begin{tabular}{llrlll}
\hline Peptide & Mol/I & $n$ & $\begin{array}{l}{ }^{14} \mathrm{CO}_{2} \\
\text { (\% of } \\
\text { control) }\end{array}$ & $\begin{array}{l}{ }^{3} \mathrm{HOH} \\
\text { (\% of } \\
\text { control) }\end{array}$ & $\begin{array}{l}\text { Lactate } \\
\text { (\% of } \\
\text { control) }\end{array}$ \\
\hline GLP-1 & $10^{-1 \mathrm{l}}$ & 7 & $133 \pm 43$ & $101 \pm 9$ & $102 \pm 11$ \\
(7-36)amide & $10^{-10}$ & 25 & $177 \pm 23^{\mathrm{c}}$ & $102 \pm 10$ & $100 \pm 3$ \\
& $10^{-9}$ & 15 & $172 \pm 33^{\mathrm{a}}$ & $119 \pm 8^{\mathrm{a}}$ & $122 \pm 10^{\mathrm{a}}$ \\
& $10^{-8}$ & 16 & $165 \pm 22^{\mathrm{c}}$ & $168 \pm 24^{\mathrm{b}}$ & $120 \pm 6^{\mathrm{c}}$ \\
& $10^{-7}$ & 11 & $160 \pm 23^{\mathrm{a}}$ & $123 \pm 18$ & $122 \pm 7^{\mathrm{b}}$ \\
Insulin & $10^{-10}$ & 5 & $140 \pm 33$ & $102 \pm 12$ & $102 \pm 12$ \\
& $10^{-9}$ & 14 & $187 \pm 40^{\mathrm{a}}$ & $206 \pm 45^{\mathrm{a}}$ & $128 \pm 11^{\mathrm{a}}$ \\
& $10^{-8}$ & 13 & $137 \pm 15^{\mathrm{a}}$ & $171 \pm 27^{\mathrm{a}}$ & $121 \pm 5^{\mathrm{c}}$
\end{tabular}

$n$, Number of experiments. ${ }^{\mathrm{a}} p<0.05 ;{ }^{\mathrm{b}} p<0.02 ;{ }^{\mathrm{c}} p<0.01$; d $p<0.001$

$(-36)$ amide $\left(10^{-10} \mathrm{~mol} / \mathrm{l}\right)$ was pre-treated with a C-terminal GLP-1 antiserum, the effect on glycogen synthesis represented $56 \pm 4 \%(n=7, p<0.001)$ of that obtained in the paired muscle incubated with the untreated peptide.

GLP-1(7-36)amide, at $10^{-10} \mathrm{~mol} / \mathrm{l}$, significantly increased synthase $a$ activity (126 $\pm 9 \%$ of control paired value, $n=14, p<0.02$ ), while it did not significantly modify the phosphorylase a control value (95 $\pm 5 \%, n=14$ ); at $10^{-9} \mathrm{~mol} / \mathrm{l}$, the corresponding mean values were similar to that at $10^{-10} \mathrm{~mol} / \mathrm{l}$ $(123 \pm 11 \%$ and $104 \pm 9 \%, n=6)$, and not different from those obtained with $10^{-8} \mathrm{~mol} / 1$ insulin $(119 \pm 7 \%$ and $93 \pm 10 \%$, respectively, $n=11)$.

Table 1 shows the glucose utilization, measured as ${ }^{3} \mathrm{HOH}$ formation from D- $\left[5-{ }^{3} \mathrm{H}\right]$ glucose and as lactate release, and the glucose oxidation, determined as ${ }^{14} \mathrm{CO}_{2}$ production from $\mathrm{D}-\left[\mathrm{U}-{ }^{14} \mathrm{C}\right]$ glucose. GLP1(7-36)amide significantly increased glucose utilization and oxidation $(p<0.001, d f=147$, by analysis of variance, at all parameters); at $10^{-10} \mathrm{~mol} / \mathrm{l}$, only the increment in glucose oxidation was statistically significant $(p<0.01)$. The three parameters were also significantly increased by insulin $(p<0.01, d f=63$, by analysis of variance).

Cyclic AMP content was neither modified by $10^{-10}$ and $10^{-9} \mathrm{~mol} / \mathrm{l}$ GLP-1(7-36)amide $(100 \pm 5 \%$ of control, $n=12$, and $102 \pm 10 \%, n=8$, respectively), nor by insulin at $10^{-8} \mathrm{~mol} / \mathrm{l}(109 \pm 10 \%, n=8)$.

\section{Discussion}

These data indicate that GLP-1(7-36)amide can directly stimulate glycogen synthesis in skeletal muscle. As is known for insulin [3], this stimulation is associated with an increase in the glycogen-synthase $a$ activity and no change in glycogen phosphorylase $a$ activity. GLP-1(7-36)amide exerted its maximal effect on glycogen synthesis at $10^{-10} \mathrm{~mol} / 1$, a concentration which has been documented as physiological [see Ref.1, for review]; this effect was abolished when the peptide was linked to a C-terminal GLP-1 antibody; at the same concentration, it also maximally stimulated glucose oxidation. In addition, at higher concentrations of the peptide, it increased the rate of glucose utilization $\left({ }^{3} \mathrm{HOH}\right.$ production from $\mathrm{D}-[5$ $\left.{ }^{3} \mathrm{H}\right]$ glucose) and lactate formation, which is an index of glycolysis in this tissue.

These insulin-like effects of GLP-1(7-36)amide on glucose metabolism in skeletal muscle could be mediated by specific receptors [8,9], but apparently not a G-protein-linked type such as that found in the pancreatic beta cell [10], since the GLP-1(7-36)amide did not increase the muscle cyclic AMP content.

Although the ultimate mechanism of this glycogenic action has not been elucidated, the data presented here suggest that skeletal muscle is one of the target tissues for GLP-1(7-36)amide, where this insulin-like effect explains, at least in part, the plasma glucose-lowering action of the peptide [2]; thus, GLP1(7-36)amide may well be implicated in the physiological control of glucose homeostasis following meals, not only by acting as an incretin, but also by directly promoting glucose disposal.

Acknowledgements. This work was supported by grants from Dirección General de Investigaciones Científica y Técnica (DGICYT, 92/0790), Fondo de Investigaciones Sanitarias (FIS, 93/0436) and Comunidad Autónoma de Madrid (CAM 92/109). We are grateful to M.E. García-Crespo, G. García and M. Valverde for their skillful technical assistance and to Ms. N. Martínez for her excellent secretarial work. A. A. and F. C. are Research Fellows from Fundación Conchita Rábago de Jiménez Díaz and E. D. is Research Fellow from Ministerio de Educación y Ciencia.

\section{References}

1. Orskov C (1992) Glucagon-like peptide-1, a new hormone of the entero-insular axis. Diabetologia 35: 701-711

2. Gutniak M, Orskov C, Holst JJ, Ahrén B, Efendic S (1992) Antidiabetogenic effects of glucagon-like peptide-1(736)amide in normal subjects and patients with diabetes mellitus. N Engl J Med 326: 1316-1322

3. Marchand-Brustel YM, Freychet P (1981) Regulation of glycogen synthase activity in the isolated mouse soleus muscle. Effect of insulin, epinephrine, glucose and anti-insulin receptor antibodies. Biochim Biophys Acta 677: 1322

4. Cuendet GS, Ernest G, Loten BJ, Renold A (1976) Decreased basal, noninsulin-stimulated glucose uptake and metabolism by skeletal soleus muscle isolated from obesehyperglycemic (ob/ob) mice. J Clin Invest 58: 1078-1088

5. Cámara J, Galera C, Valverde I, Malaisse WJ (1991) Relationship between $\mathrm{D}$-glucose oxidation and glycolysis in tumoral pancreatic islet cells with either rapid or decreased cell growth. Diabetes 17: 67-71 
6. Hue L, Bontemps F, Hers HG (1975) The effect of glucose and of potassium ions on the interconversion of glycogen phosphorylase and of glycogen synthetase in isolated rat liver preparation. Biochem J 152: 105-114

7. Fleig WE, Noether-Fleig G, Fussgaenger R, Ditschuneit H (1984) Modulation by a sulfonylurea of insulin-dependent glycogenesis, but not of insulin binding, in cultured rat hepatocytes. Diabetes 33: 285-290

8. Wheeler MB, Lu M, Dillon JS, Leng XH, Chen C, Boyd AE III (1993) Functional expression of the rat glucagon- like peptide-1 receptor, evidence for coupling to both adenylyl cyclase and phospholipase-C. Endocrinology 133: $57-62$

9. Delgado E, Alcántara A, Trapote MA, Valverde I, Villanueva-Peñacarrillo ML (1993) Identification and characterization of GLP-1(7-36)amide receptors in rat skeletal muscle. Diabetologia 36: A39 (Abstract)

10. Thorens B (1992) Expression cloning of the pancreatic beta-cell receptor for the gluco-incretion hormone glucagon-like peptide 1. Proc Natl Acad Sci USA 89: 8641-8645 